\title{
First record of the invasive medusa Blackfordia virginica (Hydrozoa: Leptomedusae) in the Río de la Plata estuary, Argentina-Uruguay
}

\author{
Primer registro de la medusa invasora Blackfordia virginica (Hydrozoa: Leptomedusae) \\ en el estuario del Río de la Plata, Argentina-Uruguay \\ GABRIEL GENZANO ${ }^{1,2^{*}}$, HERMES MIANZAN ${ }^{2,3}$, EDUARDO M. ACHA ${ }^{1,2,3}$ \& ESTEBAN GAITÁN ${ }^{1}$ \\ ${ }^{1}$ Departamento de Ciencias Marinas, Facultad de Ciencias Exactas y Naturales, Universidad Nacional de Mar del Plata, \\ Funes 3250 (7600), Mar del Plata, Argentina \\ ${ }^{2}$ Consejo Nacional de Investigaciones Científicas y Técnicas (CONICET), Argentina \\ ${ }^{3}$ Instituto Nacional de Investigación y Desarrollo Pesquero (INIDEP), Paseo V, Ocampo No 1, PO Box 175 (7600) \\ Mar del Plata, Argentina; \\ * e-mail for correspondence: genzano@mdp.edu.ar
}

\begin{abstract}
Blackfordia virginica is a well-known invasive medusa inhabiting estuarine areas. It was recently detected in northern Argentina, constituting the first record of invasive hydromedusa for the Argentine Sea. In this work

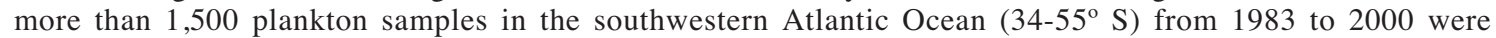
analyzed. More than 5,000 specimens per sample of B. virginica were found in Río de la Plata estuary for the first time in February 2000. This river is one of the large waterways of South America with an intense nautical traffic and several exotic species has been recorded here, mainly due to trans-oceanic shipping traffic. It is important to point out that we found medusae of both sexes (therefore this species could be introduced in either the medusa or the polyp stages or both), different size classes (including very small juveniles) and maturation stages, and in such high numbers that would suggest local reproduction. For this reason the recent finding of this hydromedusa could represent the starting point of an successful introduction.
\end{abstract}

Key words: Hydromedusae, invasive species, estuary, south western Atlantic Ocean.

\section{RESUMEN}

Blackfordia virginica es una medusa invasora reconocida por habitar áreas estuariales. Recientemente fue descubierta en el norte de Argentina, constituyendo el primer registro de una hidromedusa invasora para el mar argentino. En este trabajo se analizaron más de 1.500 muestras de plancton en el Océano Atlántico sudoccidental $\left(34-55^{\circ} \mathrm{S}\right)$ desde 1983 hasta el año 2000. Más de 5.000 especímenes por muestra fueron encontrados por primera vez en el estuario del Río de la Plata durante febrero del año 2000. Este río es una de las mayores vías de agua de América del Sur, posee un intenso tráfico náutico y varias especies exóticas se han registrado allí, principalmente debido al tráfico marítimo transoceánico. Es importante señalar que se encontraron medusas de ambos sexos (por lo tanto esta especie podría haber sido introducida en su estadio medusa, pólipo o ambos), con diferentes clases de tallas (incluyendo juveniles muy pequeños) y estadios de maduración y en números elevados, lo que haría pensar en una reproducción local. Por esta razón el reciente encuentro de esta hidromedusa podría representar el punto de partida de una introducción exitosa.

Palabras clave: Hidromedusa, especie invasora, estuario, Océano Atlántico sudoccidental.

\section{INTRODUCTION}

The finding of invasive marine species in coastal and estuarine waters is an already widespread phenomenon. The impacts of such introductions are unpredictable and not all of them become a successful resident in the new environments. The southwestern Atlantic Ocean is one of the less documented areas of the world regarding invasive species. However, a recent extensive revision indicates that unfortunately, is no longer a pristine part of the world ocean as previously thought, because many exotic marine organisms has been introduced (Orenzans et al. 2002). The Hydrozoa fauna with a medusa stage, on the other hand, was excluded from the mentioned review based on its often wide geographic ranges of distribution that may 
simply reflect its natural disperse capabilities. However, some medusae species has a not uniform spatial distribution, restricted to particular habitats, such as the medusae Blackfordia virginica Mayer, 1910, a wellknown invasive medusa inhabiting estuarine areas. It was recently detected in northern Argentina, constituting the first record of invasive hydromedusae for the Argentine sea.

Blackfordia virginica is apparently indigenous to the Black and Caspian seas, and has established in estuarine areas around the entire world (Mills \& Sommer 1995). In North America the species was recorded both in Atlantic and Pacific coasts. In Chesapeake Bay it is known since early twenty century, and in San Francisco Bay since seventies (Mills \& Ress 2000, Mills 2001). It has been also registered in several coastal lagoons along the Atlantic and Pacific coasts of Mexico (ÁlvarezSilva 1999). The sole previous record of $B$. virginica for the south western Atlantic Ocean correspond to only three specimens collected in an estuarine area near Recife (northern Brazil; $08^{\circ} 14^{\prime} \mathrm{S}, 34^{\circ} 51^{\prime} \mathrm{W}$ ), and it was probably also seen in a mangrove area close to São Paulo

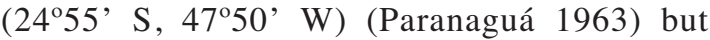
without further confirmation.

\section{RESULTS AND DISCUSSION}

As part of a project dealing with hydromedusae distributions in the southwestern Atlantic Ocean $\left(34-55^{\circ} \mathrm{S}\right)$, more than 1,500 plankton samples from 1983 to 2000 were analyzed. A large number of specimens of the hydromedusae $B$. virginica were found in Río de la Plata estuary for the first time in February 2000 (austral summer) (Fig. 1).

The Río de la Plata $\left(34-36^{\circ} 30^{\prime} \mathrm{S}, 55-58^{\circ}\right.$ $30^{\prime} \mathrm{W}$ ) forms one of the largest estuarine systems of South America (about $38,000 \mathrm{~km}^{2}$ of mixohaline area), characterized by the occurrence of a quasi-permanent salt wedge regime. Fresher, and therefore lighter, water flows out of the estuary in the surface layer and a deeper flow brings water from the sea into the estuary (Mianzan et al. 2001). The effects of the river discharge over the shelf $\left(23,300 \mathrm{~m}^{3} \mathrm{~s}^{-1}\right.$

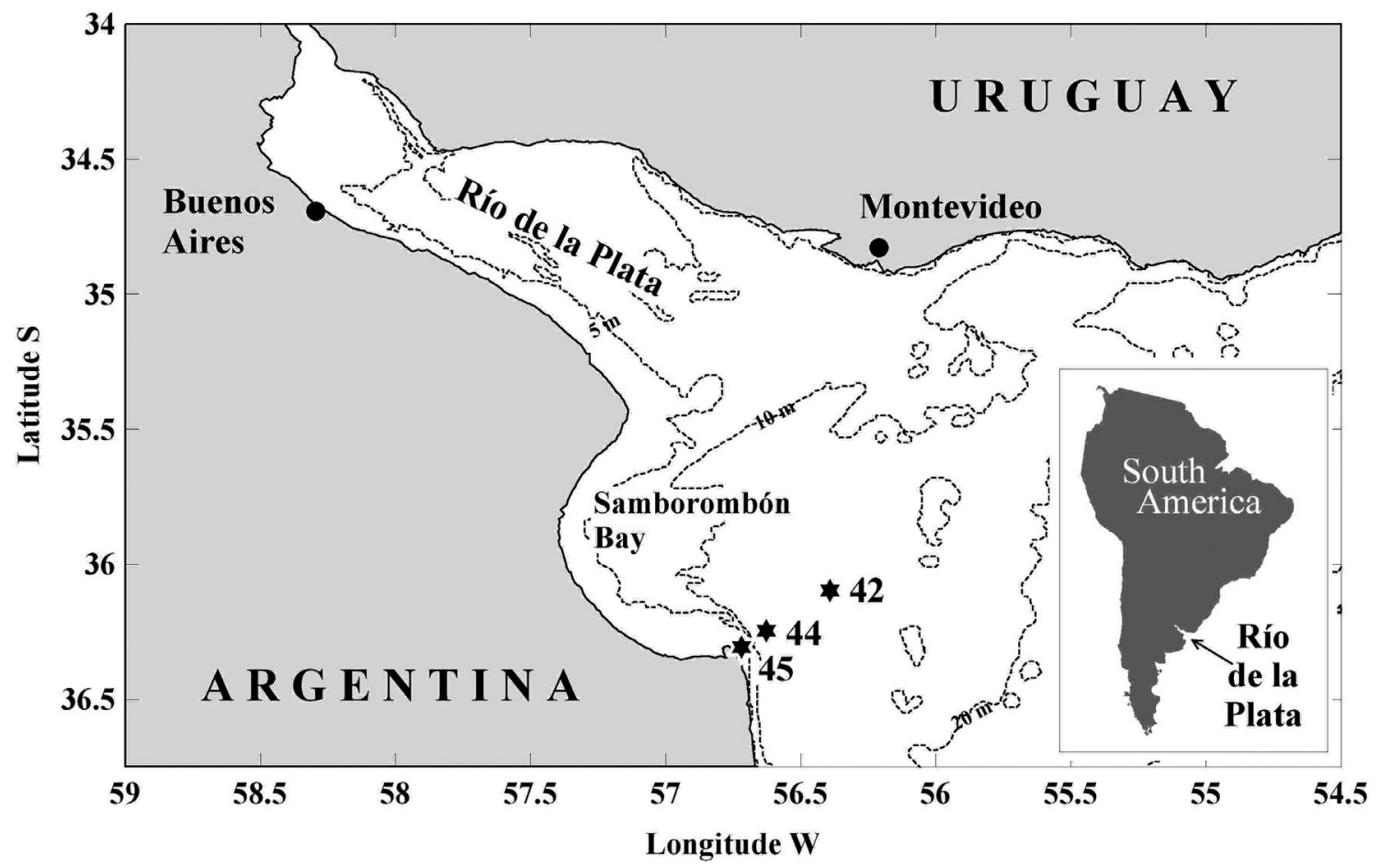

Fig. 1: Sampling stations in the Río de la Plata estuary where individuals of the medusa Blackfordia virginica where caught.

Estaciones de muestreo en el estuario del Río de la Plata donde se capturaron ejemplares de Blackfordia virginica. 
on average) manifest mostly towards NNE, and can be traced reaching southern Brazil throughout the year (Piola et al. 2000). The Río de la Plata is one of the large waterways of South America. Two of the major ports in the region, Buenos Aires (Argentina) and Montevideo (Uruguay), lie along its shores generating an intense nautical traffic. The estuary is also the maritime access to the highly complex fluvial system named "Hidrovia", communicating with the Amazon Basin.

The specimens of $B$. virginica from Río de la Plata estuary (Fig. 2A) were characterized by a bell diameter ranging from $2-10 \mathrm{~mm}$, higher than hemispherical, with rounded apex; four radial canals; a narrow short manubrium and mouth with four long fluted lips with up to 76 hollow tentacles in the bigger specimens. The

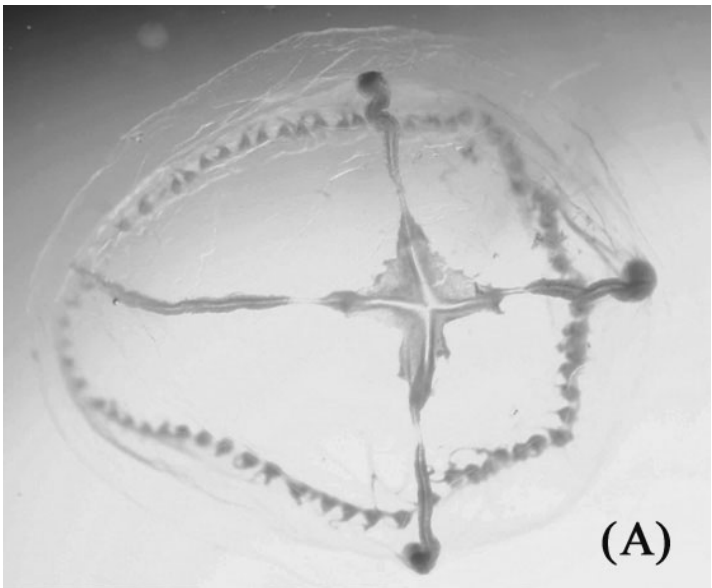

endoderm of the tentacles extends inwards from the bell margin into the mesoglea (Fig 2B). There were not permanent bulbs tentacles. Most of the analyzed medusae had only one closed estatocyst between successive tentacles. Almost $60 \%$ of the measured specimens $(\mathrm{n}=$ 157) showed linear gonads extending from the corners to the manubrium to somewhat more than half-length of the radial canals and surrounding them. Gonads occurred with low frequency in smaller specimens but they were present in all analyzed specimens bigger than 6 mm (Fig. 3). Both male and female specimens were collected. The life cycle of this species show a simple polyp stage not exceeding the $0.5 \mathrm{~mm}$ height (Mills \& Sommer 1995), which is very difficult to found in field due to its short benthic life and very small size.

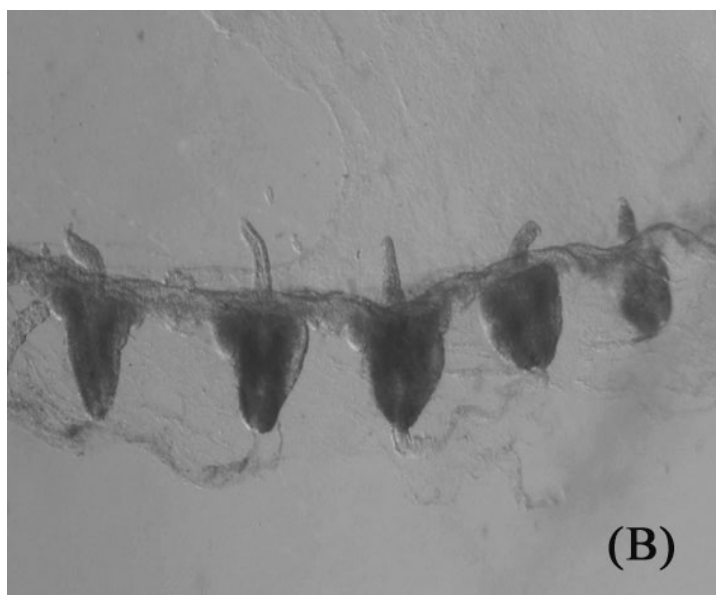

Fig. 2: (A) Blackfordia virginica from Río de la Plata estuary. (B) Detail of bell margin.

(A) Blackfordia virginica del estuario del Río de la Plata. (B) Detalle del margen de la campana.

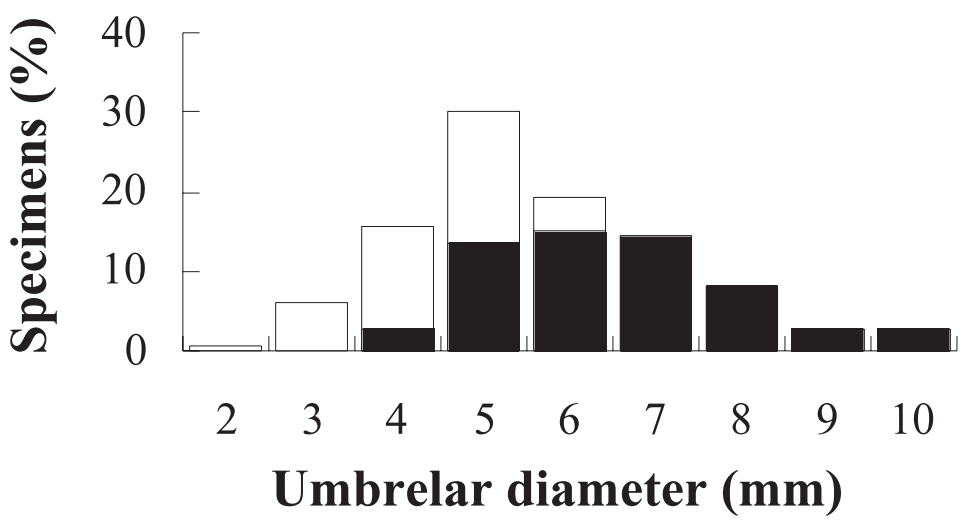

Fig. 3: Size frequency distribution of medusae Blackfordia virginica collected in the Río de la Plata estuary. White and black bars indicate specimens without and with gonads respectively $(\mathrm{n}=157)$.

Distribución de frecuencias de talla de la medusa Blackfordia virginica colectadas en el estuario del Río de la Plata. Las barras blancas y negras indican especímenes sin gónadas y con gónadas respectivamente $(\mathrm{n}=157)$. 
The analyzed medusae agree with previous descriptions of B. virginica (Kramp 1959, 1961, Naumov 1960, Bouillon 1999). Notwithstanding, bigger bell diameter, up to $22.2 \mathrm{~mm}$, has previously been recorded (Moore 1987). The usual reported number of tentacles, nearly 80 , is correlated with diameter of medusae and can be major in bigger specimens. Specimens with anomalies, both in morphology and number of radial canals and gonads, were reported for coastal lagoon of Chiapas, Mexico (Álvarez-Silva et al. 2003). Only one specimen showed anomalies (six radial canals) in the analyzed samples. Medusae occurred in three sampling stations in the southern sector of the Río de la Plata mouth. Temperature ranged between 23.5-24. $3{ }^{\circ} \mathrm{C}$. Waters showed the influence of the freshwater discharge with salinities between 23.0 and 29.7 units. In stations 42 and 44 a halocline was detected around $10 \mathrm{~m}$ in depth, while station 45 resulted vertically homogenous (Fig. 1, Table 1).

Several exotic species have been recorded in the Río de la Plata. Fish species like the silver carp Hypophthalmichthys molitrix and the sturgeon Acipenser sp., have apparently escaped from fish farms (García-Romero et al. 1998, Azpelicueta \& Almirón 1999). Another exotic Cyprinidae, Cyprinus carpio, is abundant in this area (López et al. 2003). Some others of these introductions are due to transoceanic shipping traffic. Exotic species have been transported from their native habitats by way of fouled ships' hulls, or by ballast water like the mussels Corbicula fluminea, Limnoperna fortunei and Chilina fluminea which are established several years ago (Darrigran \& Pastorino 1995a, 1995b), or the gastropod Rapana venosa recently reported by Pastorino et al. (2000).
Blackfordia virginica is well known for inhabiting and colonize different estuarine areas of the world. Having the Río de la Plata estuary such a large shipping traffic, it is expectable that many alien species be continuously injected here. This species could be introduced in either the medusa or the polyp stages or both, by nautical activities. The finding of the species does not imply a successful invasion and it is too soon to establish any impact of its presence here. However, it is important to point out that we found specimens of both sexes, different size classes (including very small juveniles) and maturation stages, and in such high numbers (more than 5,000 individuals per sample) that would suggest local reproduction. Regarding our long-term analysis of plankton (since 1983, more than 1,500 plankton samples), the recent finding of this hydromedusa could represent the starting point of an introduction of this species, allowing to begin studies on the initial phases of this process and to follow its ecological consequences. Unfortunately, no posterior samples were performed in this zone and during the same period of the year and further studies will be necessary in order to analyze if this exotic species turn into an invasive species in this new area, such as occurred in other similar environmental around the world.

\section{ACKNOWLEDGEMENTS}

This work was partially supported by Universidad Nacional de Mar del Plata, Exactas 285/03, 188/00 and 277/03, Fundación Antorchas No 13817-5 and 13900-13 and Fondo para la investigación Científica y tecnológica, Proyecto de Investigación Científica y Tecnológica $2000 \mathrm{~N}^{0}$ 07-08424. This is INIDEP Contribution $\mathrm{N}^{\circ} 1372$.

TABLE 1

Date and oceanographic measurements where individuals of Blackfordia virginica where caught

Fecha y datos oceanográficos correspondientes a las estaciones donde se capturaron ejemplares de Blackfordia virginica

\begin{tabular}{lccccccc}
\hline $\begin{array}{l}\text { Sampling } \\
\text { station }\end{array}$ & Date & $\begin{array}{c}\text { Surface } \\
\text { temperature }\left({ }^{\circ} \mathrm{C}\right)\end{array}$ & $\begin{array}{c}\text { Bottom } \\
\text { temperature }\left({ }^{\circ} \mathrm{C}\right)\end{array}$ & $\begin{array}{c}\text { Surface } \\
\text { salinity }\end{array}$ & $\begin{array}{c}\text { Bottom } \\
\text { salinity }\end{array}$ & $\begin{array}{c}\text { Sampling } \\
\text { depth }(\mathrm{m})\end{array}$ & $\begin{array}{c}\text { Individuals } \\
\left(\mathrm{m}^{3}\right)\end{array}$ \\
\hline 42 & $02-14-00$ & 23.7 & 24.3 & 24.5 & 29.7 & 15.0 & 0.013 \\
44 & $02-14-00$ & 24.0 & 23.8 & 22.3 & 27.0 & 13.0 & 0.024 \\
45 & $02-14-00$ & 23.5 & 23.5 & 23.0 & 23.0 & 1.2 & 22.08 \\
45 & $02-14-00$ & 23.5 & 23.5 & 23.0 & 23.0 & 4.2 & 29.52 \\
\hline
\end{tabular}




\section{LITERATURE CITED}

ÁLVARES-SILVA C (1999) Ampliación de ámbito de Blackfordia virginica (Leptomedusae: Lovenellidae) en lagunas costeras del Pacífico mexicano. Revista de Biología Tropical 47: 281.

ÁLVARES-SILVA C, S GÓMEZ AGUIRRE \& MG MIRANDA-ARCE (2003) Variaciones morfológicas en Blackfordia virginica (Hydroidomedusae: Leptomedusae: Blackfordidae) en lagunas costeras de Chiapas, México. Revista de Biología Tropical 51: 409-412.

AZPELICUETA M \& A ALMIRÓN (1999) A sturgeon in the temperate waters of the Río de la Plata, South America. Biogeographica 75: 129-130.

BOUILLON J (1999) Hydromedusae. In: D Boltovskoy (ed) South Atlantic zooplankton: 385-465. Backhuys Publishers, Leiden, The Netherlands.

DARRIGRAN G \& G PASTORINO (1995a) Bivalvos invasores en el Río de la Plata, Argentina. Comunicaciones de la Sociedad Malacológica del Uruguay (Uruguay) 7: 309-313.

DARRIGRAN G \& G PASTORINO (1995b) The recent introduction of the asiatic bivalve Limnoperma fortunei (Mytilidae) into South America. Veliger 38: 183-187.

GARCÍA-ROMERO N, M AZPELICUETA A ALMIRÓN \& J CASCIOTTA (1998). Hypophthalmichthys molitrix (Cypriniformes: Cyprinidae). Other exotic cyprinid in the Río de la Plata. Biogeographica 74: 189-191.

KRAMP P L (1959) The hydromedusae of the Atlantic Ocean and adjacent waters. Dana Report 46: 1-283.

KRAMP P L (1961) Synopsis of the medusae of the world. Journal of the Marine Biology Association of the United Kingdom 40: 7-469.

LÓPEZ HL, AM MIQUELARENA \& RC MENNI (2003) Lista comentada de los peces continentales de la Argentina. ProBiot A, Serie Técnica y Didáctica (Argentina) 5: $85 \mathrm{pp}$.

MIANZAN H, C LASTA, M ACHA, R GUERRERO, G MACCHI \& C BREMEC (2001) The Río de la Plata estuary, Argentina-Uruguay. In: U Seeliger \& B Kjerve (eds) Coastal marine ecosystems of Latin America 144: 185-204. Springer-Verlag, Berlin, Germany.
MILLS C (2001) Jellyfish blooms: are populations increasing globally in response to changing ocean conditions? Hydrobiologia 451: 55-68.

MILLS C \& F SOMMER (1995) Invertebrate introductions in marine habitats: two species of hydromedusae (Cnidaria) native to the Black Sea, Maeotias inexspectata and Blackfordia virginica, invade San Francisco Bay. Marine Biology 122: 279-288.

MILLS C \& JT REES (2000) New observation and corrections concerning the trio of invasive hydromedusae Maeotias marginata $(=M$. inexpectata), Blackfordia virginica and Moerisia sp. in the San Francisco Estuary. Scientia Marina 64: $151-155$

MOORE SJ (1987) Redescription of leptomedusan Blackfordia virginica. Journal of the Marine Biology Association of the United Kingdom 67: 287-291.

NAUMOV DV (1960) Hydroids and Hydrowdusae of the USSR. Key to the fauna of the USSR. Zoological Institute of the Academy of Sciences of the USSR No. 70. Translated from Russian. Israel Program for Scientific Translation, Jerusalem 1969, Catalog No. 5108.

ORENSANZ JM (LOBO), E SCHWINDT, G PASTORINO, A BORTOLUS, G CASAS, G DARRIGRAN, R ELÍAS, JJ LÓPEZ-GAPPA, S OBENAT, M PASCUAL, P PENCHASZADEH, ML PIRIZ, F SCARABINO, E SPIVAK \& EA VALLARINO (2002) No longer the pristine confines of the world ocean: a survey of exotic marine species in the southwestern Atlantic. Biological Invasions 4: 115-143.

PARANAGUÁ M (1963) Sóbre uma nova ocurréncia de Blackfordia virginica Mayer, 1910 e Oustromovia inkermanica Hadzi, 1928. Hydromedusae. Trabalhos do Instituto Oceanográfico da Universidade do Recife (Brazil) 5-6: 141-145.

PASTORINO G, PE PENCHASZADEH, L SCHEJTER \& C BREMEC (2000) Rapana venosa (Valenciennes, 1846) (Mollusca: Muricidae): a new gastropod in South Atlantic waters. Journal of Shellfish Research 19: 897-899.

PIOLA AR, EJ CAMPOS, OO MÖLLER JR, M CHARO \& C MARTÍNEZ (2000) The subtropical shelf front off eastern South America. Journal of Geophysical Research 105: 65-78. 